\title{
LARS EMANUELSSON OCH OSKAR EKMAN GUSTAF TENGGREN \\ En biografi
}

Stockholm: Kartago, 2014 (280 s.)

Gustaf Tenggren är en av de mest framgångsrika och samtidigt minst utforskade svenska illustratörerna. När man läser Lars Emanuelssons och medförfattaren Oskar Ekmans biografi, häpnar man över att Tenggrens produktion hittills har uppmärksammats i så ringa omfattning, trots konstnärens omfattande produktion och internationella betydelse. I biografin skildras Tenggrens liv och verk kronologiskt. Läsaren får följa hur den unge Tenggren målmedvetet strävar efter att bli konstnär, från studieåren vid Slöjdföreningens skola och Valands, och som tecknare i Göteborgstidningen Vidi, till rollen som John Bauers efterträdare i Bland tomtar och troll. Redan 1920 emigrerar Tenggren till USA och inleder snabbt en karriär som tidningstecknare, affischkonstnär och illustratör.

Den bild av Tenggren som framträder i biografin är den av en skicklig och formmedveten konstnär som stilistiskt sett var ytterst anpassningsbar, närmast kameleontisk. Han hade "en makalös förmåga att ta till sig olika manér" (s. 19). Tenggrens tidiga illustrationsstil inom barnlitteratur kan beskrivas som traditionell sagostil inspirerad av "The golden age of illustration" och konstnärer som Arthur Rackham, Edmund Dulac, Kay Nielsen, Louis Moe och John Bauer.

I biografin nämns även en annan tidig inspirationskälla, den finske Akseli Gallén-Kallela, vars utställning Tenggren tillsammans med Slöjdföreningens elever såg 1914. Här visar biografin övertygande hur Tenggren i en av sina målningar från samma år tydligt hämtar uppslag, såväl motiviskt som kompositionsmässigt, från den finske symbolisten. Denna intressanta iakttagelse ger prov på hur det rika och spännande bildmaterialet används i biografin. De otaliga målningarna, skisserna och originalillustrationerna får demonstrera både konstnärens utveckling och olika stilistiska perioder i konstnärskapet, men också en växelverkan mellan barnboksillustrationer, tidningsteckningar, affisch- och reklamuppdrag.

Under 1920-talet etableras Tenggren som reklamtecknare och bokillustratör i USA och han illustrerar en rad sagosamlingar, bland 
annat D'Aulnoys fairy tales (1923). Men det blir åren 1936-1939, när Tenggren arbetar som Art Director och animationschef för Walt Disney, som kommer att ha störst påverkan på hans senare gestaltning och konstsyn. När Disney inledde sin verksamhet i större skala, inspirerades han av den europeiska illustrationskonsten. Som biografin visar, anlitade Disney europeiska bildkonstnärer och tecknare för att kunna fullborda sin konstnärliga vision för sina långfilmer. Den europeiska konstnärstraditionen erbjöd den "säregna atmosfären" som Disney strävade efter och det var i detta skede som Gustaf Tenggren engagerades till Disney Studios. Skildringen av hans tid hos Disney är fascinerande läsning och trots att Tenggren var involverad i produktionen av Snövit är det framför allt hans insatser i Pinocchio som lyfts fram som grundläggande för filmens utformning och säregna stämning. Intresseväckande är även hur motiv och bearbetningar från tidigare illustrationer, i exempelvis Bland Tomtar och Troll, kunde återanvändas i de animerade filmernas bakgrundsmiljöer, men även i senare filmaffischer eller bilderböcker. Exempelvis visas hur Tenggren tydligt inspirerats av Rackham i en illustration i Bland tomtar och troll från 1924, och att samma grepp sedan används i miljöskildringar i Snövit.

Tenggren utgav även en egen bokserie, The Tenggren Books, som kom ut från 1920-talet fram till mitten av 1950-talet. Här demonstreras hur konstnärens stil under 1940-talet radikalt ändras, mot en mer ytdekorativ stil med plana färgytor och något stelare gestaltning. Samtidigt utgör denna förenkling grunden för några av Tenggrens mest populära bilderböcker inom Little Golden Books-serien. Hans arbete på Disney, liksom hans framgångsrika medverkan i Little Golden Books under 1940-talet, sammanfaller med en period då nya medier och en ny typ av massmarknadsutgivning framträder på bred front. Denna typ av utgivning blir betydelsefull även inom det barnlitterära fältet, och påverkar inte minst bilderbokens uttryck och utgivningsformer. Både i form av direkta influenser men även i form av kritiska motreaktioner lämnar den populärkulturella utgivningen sina spår även i den svenska barnlitteraturen. I vissa fall, som i exemplet med Bland tomtar och troll ovan, sker denna rörelse dessutom i båda riktningarna.

Att forskningen kring Tenggren hittills varit så begränsad i Sverige speglar förmodligen hans starka kopplingar till massmarknadslitteratur och -medier. Exempelvis inkluderas han inte i det nyligen utgivna praktverket Svensk illustration. Detta kan möjligen förklaras av att Tenggren efter sin emigrering 1920 aldrig återvände till Sverige. Han hamnade snabbt i medieskugga här hemma och har därför 
länge varit relativt okänd i Sverige, trots de enorma framgångarna i USA. Samtidigt utgavs några av hans bilderböcker, inte minst den storsäljande The Poky Little Puppy (Den nyfikna hundvalpen), liksom The Saggy Baggy Elephant (Den skrynkliga elefanten), i FIB:s Gyllene böcker under 1940- och 1950-talen. The Poky Little Puppy är ytterligare ett exempel på konstnärens popularitet; fortfarande år 2002 var boken den mest publicerade barnboken i USA. Tenggrens produktion kan alltså ses som en del av den tidiga, globala masskulturen, men hans bildspråk bygger tydligt på förra sekelskiftets nordiska och nordeuropeiska bildtradition och bokillustration, något som även biografin visar.

Det som belyses i boken är alltså en dynamisk växelverkan mellan illustrationskonst, bilderboken och andra medier. Liksom Tenggren livnärde sig många av bilderboksillustratörerna i början av seklet som tidningstecknare eller på reklamateljéer, en bakgrund som är högst relevant i studier av dessa konstnärers barnlitterära produktion. Stundtals hade en fördjupning av dessa områdesöverskridande förflyttningar kunnat vara fruktbart. Hur förhåller sig till exempel de många exotiserande dragen i reklamuppdragen från 1920-talet till sagogenren? Det är uppenbart att den nordiska stilen och de svenska sagomotiven uppfattas som exotiska i den amerikanska kontexten - något som även utnyttjades av konstnärskollegan Einar Nerman som under perioder arbetade i England och i USA, och som bland annat i Fairytales from the North (1946) tolkade nordiska sagor och folkloristiska motiv. Läsaren erbjuds en sällsam bildkavalkad av såväl sagoillustrationer som exotiserande motiv i reklambilder från detta årtionde, och en diskussion om exotismen, liksom den fascinerande växelverkan som visas mellan sagoillustrationer och reklam, hade möjligen kunnat utvecklas ytterligare.

Lars Emanuelssons betydande samlingsarbete och forskning av Tenggrens produktion har möjliggiort en grundlig och intressant skildring av konstnärskapet där bildmaterialet har en framträdande och viktig plats. Särskilt uppskattar jag analyserna om Tenggrens teknik och stilistik, och att Emanuelssons, med sin bakgrund som tecknare och illustratör, har en skarpsynt blick för såväl konsthistoriska som reklamhistoriska sammanhang och influenser. Lars Emanuelssons och Oskar Ekmans biografi är en rikligt illustrerad och ypperligt formgiven bok som är ett värdefullt bidrag till den svenska barnlitterära och illustrationshistoriska forskningen.

Elina Druker

Docent i litteraturvetenskap Institutionen för kultur och estetik Stockholms universitet 